\title{
PreK-5 Teacher Views of Professional Development Integrating Common Core Language Arts With Science and Social Studies
}

Janie Hubbard, EdD

The University of Alabama, Tuscaloosa, Alabama, United States

(iD) https://orcid.org/0000-0002-1163-9673

Melisa Fowler, EdD

The University of Alabama, Tuscaloosa, Alabama, United States

Lee Freeman, EdD

The University of Alabama, Tuscaloosa, Alabama, United States

Contact: hubba018@ua.edu

\section{Abstract}

Three preK-6 U.S. university methods instructors-researchers (literacy, science, social studies) joined 17 Title I school teachers for collaborative lesson planning and teaching within the preK -5 school setting. Each team's goal was to create and teach interdisciplinary curriculum units using U.S. English language arts Common Core State Standards with social studies and science. A year-long instrumental case study design was used to examine (a) how teachers perceived collaborative professional development to create interdisciplinary unit plans and (b) how teachers viewed outcomes of teaching interdisciplinary units of their own design. Practice articles regarding Common Core State Standards curricula integration are plentiful; however, this study offers researched insights.Collectively, research from various locations and school cultures benefits those needing to structure realistic professional development designs.

Keywords: U.S. Common Core Standards; preK-5 education; science education; social studies education; jobembedded professional development; interdisciplinary education

Date Submitted: July 17, 2019 | Date Published: March 9, 2020

\section{Recommended Citation}

Hubbard, J., Fowler, M., \& Freeman, L. (2020). PreK-5 teacher views of professional development integrating common core language arts with science and social studies. Journal of Educational Research and Practice, 10, 1-25. https://doi.org/10.5590/JERAP.2020.10.1.01

\section{Introduction}

U.S. school administrators constantly face top-down national, state, district, and schoolwide reform movements, which evolve into policies directly affecting classroom teachers. Policies are loaded with promise and hope that our young students-no matter their background, status, language proficiency, and 
Hubbard et al., 2020

so forth-will achieve well on standardized tests and, perhaps, surpass other countries. Reform movements are inevitable in U.S education and have been throughout history.

In the broadest sense, change can be good, though at a grassroots level, teachers' professional learning to implement new standards, curricula, pacing, and technologies is perplexing to say the least. As reforms and policies change, it is difficult to know the most efficient use of time and resources for various professional development (PD) needs. Educational researchers, therefore, depend on experiments with real classroom teachers in attempts to formulate elusive recipes for success.

This discussion describes one such experiment with 17 local Title I school teachers over 1 year. Best practices for PD are espoused in literature, though understandably, they do not aspire to suggest success in every context. School settings can be hectic places - not in a bad way, but in human, unpredictable ways. Geographic locations, within the United States, determine demographics, teaching and learning environments, assumptions, needs, support, funds, time, teachers' education, and so forth. Further, all reform movements require policy change, but not every U.S. state is willing to accept or commit, longterm, to such changes. These are a few reasons why varied, first-hand, experiences from all U.S. areas must be documented.

Each individual experiment or case, especially embedded within the regular school day, helps researchers, educators, administrators, curriculum developers, and those responsible for staff development more deeply understand imperceptible influences within each locale. The following sections, describing this particular study, present background information, relevant literature review, purpose, theoretical framework, methodology, findings, discussion, and conclusions.

\section{Background}

At the onset of this project, Highlands Elementary School's (pseudonym) principal provided an informal needs assessment. She met with the authors (three university methods instructors) and discussed teachers' insecurities regarding how to unpack and use the English language arts (ELA) Common Core State Standards (CCSS) when applied to disciplinary content. In brief, CCSS documents require particular disciplinary content, stating, "Informational reading includes content-rich nonfiction in history/social studies, sciences, technical studies, and the arts. The $\mathrm{K}-5$ standards strongly recommend that texts - both within and across grades-be selected to support students in systematically developing knowledge about the world" (CCSS Initiative, 2019b, para. 10).

\section{Literature Review}

PreK-6 social studies education. The National Council for the Social Studies (1994) defined social studies in this way:

[the] integrated study of the social sciences and humanities to promote civic competence. Within the school program, social studies provides coordinated, systematic study drawing upon such disciplines as anthropology, archaeology, economics, geography, history, law, philosophy, political science, psychology, religion, and sociology, as well as appropriate content from the humanities, mathematics, and natural sciences. (p. 3). 
It is generally understood by preK-6 social studies educators that it is the early childhood/elementary educator's responsibility to ensure young students gain understanding of foundational concepts (e.g., citizenship, needs, wants, location, directionality, landforms, government, cultures, and more). Further, skills (e.g., critical thinking, inquiry, debate, evidenced-based decision making, negotiation) are introduced and developed during the early years. It is well documented, though, that social studies has long been marginalized in U.S. schools-many think this is due to focused attention on government mandated tested subjects of which social studies is not included (see Bailey et al., 2006; Christensen et al., 2001; Haas \& Laughlin, 2001; Hubbard, 2013). Consequently, there has been little PD, and teachers admit that they do not know how to teach social studies.

\section{PreK-6 Science Education}

PreK-6 science education's vision offers students opportunities to develop and use models, plan and carry out investigations, and engage in argument from evidence. Being science and engineering literate requires one to participate in scientific processes. Young students learn reading comprehension while also gathering, evaluating, and communicating data; however, this should not be the extent of a student's scientific instruction (Huff, 2016). Comparable to preK-6 social studies, state and federal policies marginalize disciplinary science curricula in deference to massive literacy teaching and learning (Cervetti et al., 2006). Further, many elementary school teachers “... don't like science, they don't feel confident in their knowledge of science, and they don't know how to teach science effectively" (Allen, 2006, para. 1).

\section{Professional Development Practices}

In this project, we believed our PD model aligned with known best practices. Authorities on this topic, Linda Darling-Hammond and colleagues (2017) reviewed PD research for over 30 years. Through this work, they identified commonly shared characteristics of effective PD, which are listed here: (a) content focused, (b) incorporates teachers' active learning; (c) supports collaboration, often in job-embedded contexts; (d) models effective curricular and instructional practice; (e) provides coaching and expert support; (f) time for feedback and reflection; (g) sustained duration; and (h) provides teachers with adequate time to learn, practice, implement, and reflect upon new strategies (p. v). "Providing teachers with real training and templates, not scripts and work sheets, and meaningful opportunities to work together to implement strategies that will improve student learning, are critical components of any strategy to implement the common core" (Phillips \& Hughes, 2012, para. 14). Collaborative PD models for educators are generally widespread and essential for taking teachers out of isolation to learn with and from colleagues.

Current models such as lesson study, observation-assessment, open classrooms, study groups, and looking at students' work are teacher-centered, collaborative, and globally applicable (Burns, 2014). Another popular collaborative model is the professional learning community (PLC; Darling-Hammond et al., 2017; DuFour, 2004). Primarily, educators within a PLC and those who support a PLC will (a) focus on learning versus teaching; (b) recognize that working collaboratively produces dialogue and action needed to achieve the collective purpose of learning for all; (c) remove barriers to success (e.g., give teachers time to analyze and discuss state curriculum documents); (d) focus on results and working together to achieve goals (e.g., results may require educators to change traditional practices, revise assumptions, avoid limiting improvement goals to factors outside the classroom); and (e) persist and commit to improvement and student learning.

Our proposed interdisciplinary PD model contained many of these attributes: job-embedded, collaborative, included demonstration lessons that modeled instruction, centered on evidence-based practices and content, offered time for planning, curriculum implementation with students, reflection, 
Hubbard et al., 2020

and focused on discipline-specific curriculum development. Discipline-specific, in this project, meant that science and social studies content, derived from state grade-specific curriculum standards, merged together and also with ELA CCSS.

\section{Curriculum Integration}

Differences in disciplinary approaches are defined, within this summary borrowed from Alexander Refsum Jensenius (2012):

1. Intradisciplinary: working within a single discipline.

2. Cross disciplinary: viewing one discipline from the perspective of another.

3. Multidisciplinary: people from different disciplines working together, each drawing on their disciplinary knowledge.

4. Interdisciplinary: integrating knowledge and methods from different disciplines, using a real synthesis of approaches.

5. Transdisciplinary: creating a unity of intellectual frameworks beyond the disciplinary perspectives. (para. 3)

Integration is not new, thus various designs (e.g., interdisciplinary, thematic, multidisciplinary, problembased) for organizing integrated curricula are well documented. These models serve as guides for teachers who select integrated instruction as an approach for teaching elementary curricula. Integration, simply defined here, means that a unique curriculum is created by crossing disciplines that may share meaningful concepts, ideas, skills, and questions (Ross, 2016). Interdisciplinary integration can be ideal for preK-6 grades, as many classrooms are self-contained. In other words, one teacher may be responsible for teaching all subjects (e.g., science, social studies, reading, writing, mathematics) in one classroom, with the same students all year.

Practical ideas meant to plan and implement lessons using K-6 ELA CCSS with science and social studies content standards are present in the literature, though more actual research studies are needed. For example, Bogan et al. (2012) supported the Bogan differentiated instruction model, which requires the teacher to select a common core standard for reading, science, and social studies and connect them for contextual teaching. The lesson planning format is designed for both interdisciplinary teaching and differentiated instruction. Another practice-oriented model, the explanation framework, is used to advance literacy across science, public speaking, ELA, and social studies. The claim is that this tool helps students communicate explanations based on science phenomena, literacy ideas, historical events, and perspectives (Novak et al., 2016). Primarily, though, existing literature describes teacher-tested pedagogies. For instance, Gregory (2015) offers a lesson plan focused on CCSS reading, writing, listening, and speaking standards integrated with social studies and science to introduce students to various argument concepts. In short, most articles are practice-based (e.g. Joyce \& Calhoun, 2015; Kandel \& Brew, 2015; West et al., 2016).

When considering CCSS and content integration separately, a few research studies surface. For example, Denton and Sink's (2015) case study involving elementary teachers and social studies embedded within other content subjects (not with CCSS) shows integration as the preferred approach, though participants stated that time, limited training, and inadequate resources inhibited their use of effective social studies integration with other disciplines. Nowell (2017) studied three social studies teachers' perceptions of CCSS literacy integration in Oklahoma, finding that teachers were most concerned with filling grade-to- 
grade, vertical curricular gaps and cultural diversity components lacking in CCSS assessments. Teachers, however, credited PD and teacher PLC networks with planning and implementation successes. Pryor et al. (2016) investigated the beliefs that formed 6o elementary, middle, and secondary teachers' intentions to integrate science, technology, engineering, mathematics content into their social studies instruction. Findings claim the potential to influence teachers' beliefs, attitudes, and intentions to integrate science, technology, engineering, mathematics into social studies, which could ultimately lead to affecting teachers' beliefs about other interdisciplinary possibilities.

\section{Purpose}

Overall, this research explored the effects of interdisciplinary unit planning and implementation as a form of collaborative job-embedded PD (JEPD) for $\mathrm{K}-5$ teachers. Science and social studies disciplinary content were extracted from state standards for each grade level. We wanted to understand how teachers viewed planning interdisciplinary lessons and units, on the job, and then teaching their own designed lessons within classrooms to test the lessons' effectiveness with students. In other words, this would be teachers' assessments of the experience. Research questions were:

Research Question 1. How do teachers perceive collaborative PD to create interdisciplinary unit plans?

Research Question 2. How do teachers view outcomes of teaching interdisciplinary units of their own design?

This instrumental case study (Thomas, 2011) employed mixed-methods to answer the research questions. The process emphasized detailed contextual analysis of a limited number of events and conditions and their relationships within a natural school setting. This "inquiry was meant to serve a particular purpose, thus the case study acts as an instrument-a tool" (p. 98). The purpose was to understand a process from teachers' perspectives. The research spanned 1 year, May through May. Data gathering methods and analyses are explained in the methods section, and instruments are appended.

\section{Theoretical Framework}

In the broadest sense, curriculum theory drives the investigation. Early conversations emphasized that, in isolation, the theory is valueless, because it is the sequence derived from curriculum theory that finally makes it to the classroom. Curriculum theory leads to learning theory, which leads to instruction theory, and then curriculum development. Morris and Hamm (1976) presented one interpretation of curriculum theory's primary characteristics: (a) the major concern is with process or product knowledge rather than learning, and (b) it deals with alternative intellectual structures to organize what is worth knowing. The real focus is on educational experience. William Pinar (2012) reiterates that curriculum theory is a scholarly effort to understand curriculum, a "complicated conversation" of what knowledge is of most worth (p. 2). Curriculum models, then, should extend access to the best knowledge we have (Young, 2015).

Theoretically, curriculum integration or interdisciplinary curriculum models have capacity to efficiently organize what knowledge is of most worth and methods for how it is taught. James Beane (1997) defines a discipline of knowledge as "a field of inquiry about some aspect of the world-the physical world, the flow of events over time, numeric structures, and so on.” He stated, “...refining relationships between curriculum integration and disciplines of knowledge is easy” (p. 616). However, students must have 
opportunities to engage in seeking, acquiring, and using knowledge in organic, holistic, authentic ways to broaden their understanding of themselves, the world, and how to communicate what they know. An important argument for this research project is that those "complicated conversations" (Pinar, 2012), amongst educators, offer insights about refining curricula; thus, teacher collaboration should be ideal for such a challenge.

\section{Method}

This research employed mixed methods to answer two research questions. Data gathering methods included pre- and poststudy teacher surveys, pre- and poststudy teacher focus group interviews audiotaped and transcribed, work samples, and teaching observations. Researcher-journals were used to record project processes throughout the year (e.g., meeting notes, PD outcomes, discussions, debriefings).

\section{Setting}

The Title I school, Highlands Elementary, serving grades preK-5, is located in a southeastern U.S. county public school district. The non-White population is $80 \%$ (state average is $43 \%$ ), and most are African American. Seventy-three percent of students are eligible for free lunch and $5 \%$ for reduced lunch (Public School Review, 2019). "Despite its limitations, the free/reduced price lunch data are frequently used by education researchers as a proxy for [U.S.] school poverty since this count is generally available at the school level, while the poverty rate is typically not available" (Snyder \& Musu-Gillette, 2015, para. 5). Schools, such as Highlands, "...enrolling at least 40 percent of children from low-income families, are eligible to use Title I funds for school wide programs designed to upgrade their entire educational programs to improve achievement for all students, particularly the lowest-achieving students" (U.S. Department of Education, Office of Elementary and Secondary Education, Office of State Support, 2015, para. 2). Highlands Elementary is over 60 years old, enrolls approximately 320 students per year, and maintains about a 20:1 teacher-to-student ratio.

A large university is located $6 \mathrm{mi}$ from Highlands Elementary School, and a relationship between the two institutions developed over approximately 15 years. Primarily, university preservice practicum teachers and interns are placed with Highlands's cooperating teachers, teacher education program literacy course students often work with small elementary student groups there, and Highlands has hosted several rounds of teacher education program interviews for prospective elementary education majors.

\section{Participants and Procedures}

Through discussions with the school's principal, in May of the first year, we learned that Highlands's teachers needed PD centered on how to use CCSS English language arts standards with science and social studies content. That summer, we met with the Highlands's faculty during a scheduled work day and presented a proposal to assist teachers in implementing PD on the school site. We described procedures for collaboratively unpacking the CCSS and science and social studies state curriculum standards to plan grade-level lesson plans. After sharing the intended scenario for collaborative PD and goals, we modeled two integrated lessons that included Highlands faculty's active interaction; one lesson focused on early childhood social studies and another on fourth-grade science.

We left a sign-up sheet for teachers, at the school, to indicate their interests in participating in the described PD. The next week, when we retrieved the sign-up sheet, there were 16 volunteers ranging from kindergarten to fifth grades. We scheduled meetings with each grade-level team and, again, described our vision of a collaborative learning community at the school. Teachers who agreed to involve themselves in 
the research, signed informed consent. Volunteers, though, were welcomed into teams with or without involvement in the study. We consider the participants a convenience sample because we were invited, by the principal, into their space to assist with PD. Sixteen volunteer $\mathrm{K}-5$ grade teachers worked in teams. One preK teacher chose to join the kindergarten team, making 17 participants in all. Participants ranged in teaching experience from 1 year $(n=2), 3-7$ years $(n=8)$, 9-13 years $(n=5)$, and 20-22 years $(n=2)$. The principal and a reading coach oversaw the project. As teacher-researchers, we were experienced career educators each having taught over 16 years in various elementary schools within different geographic locations, now university methods instructors.

\section{Data Sources}

\section{Prestudy data sources}

Participants completed prestudy surveys (Appendix A) regarding their perceptions of planning and implementing lessons using the ELA CCSS to integrate and teach science and social studies. Individuals were requested to check "yes" or "no" in areas to indicate their beliefs about needing JEPD for planning purposes. The survey contains 13 questions related to the following: (a) understanding why the approach might be useful; (b) understanding how the approach could be used; (c) developing daily lesson plans; (d) developing long-term units; (e) using engaging strategies; (f) using technological techniques; (g) accommodating individual student needs; (h) time management strategies; (i) incorporating critical thinking; (j) formative and summative assessment; (k) communication with parents, students, and other teachers; (l) creating and fostering collaborative learning communities; and (m) learning about locating resources.

The survey's second phase directly asked participants to answer five questions primarily about collaborative participation and implementation of lessons with their students. Questions included what their perceived challenges, concerns, questions, perceptions were about their earlier participation in our demonstration lessons. As researchers, we were trying to access their ideas of how lessons integrating ELA CCSS with science and social studies standards, in which they participated, actually affected them. That is, did planning and implementing lessons like these seem feasible and worthwhile? We also wanted to learn teachers' perceptions about participating in JEPD to coplan integrative lessons or units. Prestudy focus group interviews, using six open-ended questions, were used to capture additional data regarding teacher perceptions (see Appendix B).

\section{Collaborative meeting procedures}

First, we funded half-day substitute teachers with a small university grant, so participants could co-plan within $\mathrm{K}-5$ teams. With each of the six teams $(\mathrm{K}-5)$, we worked to unpack ELA CCSS and science and social studies state standards. We used a lesson plan organizer/template requested by the school principal, and we designed units by weaving objectives, essential questions, concepts, skills, and assessments together. Using websites, standards, and other resources, we brainstormed engaging lesson activities for students. Through discussion, additional curriculum standards guided our growing units. Second, volunteer participants taught new unit lessons to students, as we observed. Third, debriefing meetings, with teachers, followed lesson observations. Before teaching, each teacher was offered $\$ 100$ cash to buy materials for implementing one lesson-no formal paperwork requests were required.

Using a lesson study observation protocol (Stepanek et al., 2007), we collected data through classroom observations while teachers taught newly created lessons. We kept researcher journals to record project processes (e.g., meeting notes, PD outcomes, discussions, debriefings). Lesson documents, which eventually evolved into unit plans were supplementary data. 
Hubbard et al., 2020

\section{Poststudy data sources}

Participants completed poststudy surveys (Appendix C) moderately adapted from the prestudy survey. Individuals indicated "yes" or "no" to 13 questions about their perceptions of knowledge gained through project participation (e.g., developing daily lessons, using engaging strategies, time management strategies). For example, Question 3 states, "Did you gain knowledge about how to develop daily lesson plans that use ELA CCSS to teach social studies and science?" A third survey area requested participants to check a box if they believed additional JEPD was needed for any of the 13 criteria. The poststudy survey's phase two contain five questions that, to an extent, mimic the prestudy survey. Poststudy questions were consistent with data gathering about challenges, concerns, questions, and perceptions. A Likert scale style questionnaire, located on the survey, requested participants to disclose information about their students' overall academic achievement, interest/enjoyment, motivation, involvement, curiosity, confusion, and acceptance regarding lessons that their teachers collaboratively planned and implemented with students. The survey's last component asked for additional comments. A poststudy focus group interview, using seven open-ended questions, was created to collect further data regarding participants' perceptions (see Appendix D).

\section{Data Analysis}

Overall, case study research used mixed methods to examine the effects of interdisciplinary unit planning and teaching as a form of collaborative PD for teachers on the job. Data were analyzed using constant comparative methods; the principle of going through data again and again, emerging with themes that summarize the data. Data to answer the first research question primarily derived from pre- and poststudy teacher surveys and transcribed interviews. We counted and compared teachers' responses to the distinct survey-like questions, pre- and poststudy. However, pre- and poststudy teacher surveys also included direct, open-ended questions; therefore, those question responses, along with interview transcriptions, were analyzed using a grounded theory approach (Strauss \& Corbin, 1990). During open coding, we divided the data into similar groupings, forming preliminary categories of information about the phenomenon being studied. Next, through axial coding, we began to bring the categories together as themes and then used selective coding to organize and articulate themes for more coherent understanding of the phenomenon (Strauss and Corbin, 1990, 1998). Kimberly Neurendorf, 2002) described interpretative analysis as involving analytical categories, being cumulative, a type of comparative analysis, and including the formation of categories, wherein "the analysist is in a constant state of discovery and revision" (p. 6). The technique was a type of message analysis used, in this study, to further develop themes from the observation of messages and the coding of those messages.

\section{Findings}

Overall, research explored the effects of $\mathrm{K}-5$ interdisciplinary unit planning and implementation as a form of collaborative JEPD for teachers. Fourteen of 17 participants completed the prestudy survey (Appendix A). Survey results revealed all respondents believed they needed PD to help them use ELA CCSS to teach social studies and science. Table 1 displays measures most to least frequently cited. Note that some respondents did not answer every question.

Table 1. In-Service Teachers' Prestudy Survey: Perceptions of Job-Embedded Professional Development (PD) to Help Use English Language Arts Common Core States Standards to Teach Social Studies and Science 


\begin{tabular}{cccccc}
\hline & & Respondents, & \multicolumn{2}{c}{ Need PD? } & \\
Question & Criteria & $\boldsymbol{n}$ & Yes & No & Percent Yes \\
\hline Q9 & Critical thinking & 14 & 12 & 2 & $86 \%$ \\
Q3 & Lesson planning & 14 & 11 & 3 & $79 \%$ \\
Q12 & Learning communities & 14 & 11 & 3 & $79 \%$ \\
Q2 & Understanding how & 12 & 9 & 3 & $75 \%$ \\
Q10 & Assessment & 14 & 10 & 4 & $71 \%$ \\
Q4, Q5, Q6, Q8 & Units, strategies, technology, & 14 & 9 & 5 & $64 \%$ \\
Q7 & time management & & & & \\
Q11 & Accommodation & 14 & 6 & 8 & $43 \%$ \\
Q1 & Communication & 13 & 5 & 8 & $38 \%$ \\
Q13 & Understanding purpose & 13 & 4 & 9 & $31 \%$ \\
& Locating resources & 8 & 4 & 4 & $50 \%$ \\
\hline
\end{tabular}

Prestudy survey data showed that most participants believed they needed JEPD to learn how to incorporate critical thinking (86\%) into integrative lesson plans. Lesson planning, creating learning communities with coworkers, and understanding how to create lessons and assessments using ELA CCSS with social studies and science were average or above (71-79\%) in perceived need. Some participants determined that accommodating students' needs, communication with parents, students, and other teachers about the process were necessary, though those ranged from a low $31 \%$ to $43 \%$.

Prestudy focus group interviews (Appendix B) occurred in four separate sessions with a total of nine volunteer participants. Interviewees were $\mathrm{K}-3$ teachers, and the school's principal entered one session and spoke. We coded the interview transcriptions separately, met, and reached agreement at approximately $90 \%$. Table 2 displays major thematic categories for nine participants. Other responses were too few to categorize.

Table 2. Prestudy In-Service Teachers' Focus Group Interview Categories

\begin{tabular}{lc}
\hline \multicolumn{1}{c}{ Category } & Responses, $\boldsymbol{n}$ \\
\hline Time anxiety & 5 \\
Coverage anxiety & 5 \\
Resistance and/or scripted program driven & 5 \\
Open to new ideas or change & 5 \\
See value/make connections/appreciate freedom & 5 \\
Want guidance & 4 \\
No time for social studies or science & 4 \\
Other (resources, collaboration) & 3 \\
\hline
\end{tabular}

These example statements, gathered from focus group interviews, illustrate the issues:

It will give you more time to teach science and social studies because normally science and social studies is on our back burner. Like thirty minutes here, and it's not science AND social studies. It 
Hubbard et al., 2020

is science OR social studies. So, with integrating them, it will give you more time to focus on those. (Grade 3, Participant 3)

My concern is just finding the time to get everything in and make sure we do it to fidelity and that we are teaching them exactly what the state wants, because it's different. (Grade 3, Participant 1)

I think it kind of goes back to what [Participant 6] was just saying...making sure we cover everything...umm...you know as a grade level we think it's [CCSS] to do it and keeping up with it, but still you have that fear that you're missing something. (PreK-K, Participant 4)

I feel much better about it [interdisciplinary lesson planning] right now that I am just meeting so many more standards in one lesson instead of having reading... and unrelated to what's going on by season or, you know, how we usually do social studies. (PreK-K, Participant 6)

Resources is something I am worried about. I will admit science and social studies has definitely been on the back burner. I need to work on that, but finding the materials for science... [unfinished sentence]. (Grade 1, Participant 8)

...the concerns that you had (nodding to teacher) about will I cover it all...trust me, principals feel the same thing....I know it's a lot of work for you, and I am really concerned about that, but I am also excited to see what is going to come for our kids. That is the reason I am kind of sitting in today. I think it is important for our students. So, thank you for what you are doing. (Principal [visited during Interview 3])

After planning lessons and units with each $\mathrm{K}-5$ team, we sent each teacher (whether they were participants or not) their team's completed unit via email. Then, at a Highlands's school faculty meeting in early January, we gave each teacher a curriculum unit in booklet form. Each participant received a poststudy survey, and we asked to retrieve the completed surveys the following week. We also left a teaching observation schedule and asked volunteers to sign the schedule with date, time, and whether or not they desired one of us to coteach or help in the classroom.

Five volunteers agreed to classroom observations with two asking for classroom assistance, two said, "maybe," and a fifth participant said, "no." All five observations occurred January 14-16. Though 17 teachers volunteered and engaged in half-day JEPD sessions, five teachers implemented unit lessons or parts of lessons with their students. Lesson observations showed mixed results between teachers who struggled with planning and implementing lessons and those who embraced the process. During debriefings, some teachers disclosed beliefs that the content was too difficult for students to comprehend. Four of 17 participants completed the poststudy survey (Appendix C). Table 4 displays a numerical results summary. 
Hubbard et al., 2020

Table 4. In-Service Teachers' Poststudy Survey: Perceptions of Job-Embedded Professional Development (PD) to Help Use English Language Arts Common Core States Standards to Teach Social Studies and Science (Respondents = 4)

\begin{tabular}{ccccc}
\hline & & \multicolumn{2}{c}{$\begin{array}{c}\text { Knowledge } \\
\text { gained? }\end{array}$} & More PD \\
Question & Criteria & Yes & No & \\
\cline { 3 - 4 } & Wheeded \\
\hline 1 & How integration & 4 & & \\
2 & Daily lesson plans & 4 & & 2 \\
3 & Long-term units & 4 & & 2 \\
4 & Strategies & 3 & 2 & 2 \\
5 & Technological techniques & 3 & 2 & \\
6 & Accommodation & 3 & 2 & \\
7 & Time management & 3 & 2 & \\
8 & Critical thinking skills & 4 & & \\
9 & Assessment & 3 & & \\
10 & Communication & 3 & 1 & \\
11 & Learning communities & 3 & 1 & \\
12 & Resources & 3 & 1 & \\
13 & & & & \\
\hline
\end{tabular}

A few example quotes from the open-ended survey questions are presented in Appendix E. This poststudy data showed that even though some participants responded to more than one yes/no question, at least, two participants perceived that little knowledge was gained about engaging strategies, technological techniques, accommodations for students with special needs, and time management. While participants responded to open-ended questions (see Appendix C), Mr. Jones, a third-grade teacher, was the only participant who agreed to a poststudy face-to-face interview. We interpreted some limitations of the study (see below) as actual factors causing the lack of participants volunteering for a final interview.

Poststudy teacher perceptions showed that all those responding believed, through their participation, they gained knowledge in various areas related to integrating ELA CCSS with science and social studies (e.g., lesson planning, strategies, time management, critical thinking). Assessment was the one area most noted as a deficit. Poststudy responses continued to name lack of resources and time as primary challenges. Nonetheless, one question still lingers regarding resource and time deficits. Why did 16 of 17 teachers leave funds for resources ( $\$ 100$ per lesson) and planning time, approved by the principal with substitute teachers (paid with grant funding), on the table?

\section{Discussion}

This research examined (a) how teachers perceived collaborative PD to create interdisciplinary unit plans and (b) how teachers viewed outcomes of teaching interdisciplinary units of their own design. All data demonstrated that participating teachers perceived collaborative, interdisciplinary unit planning and teaching outcomes positively, before and after PD sessions, yet they were plagued, primarily, by fears regarding content coverage and time. Teachers never said the process was ineffective, though, what they did not say (omissions) speak volumes. 
Hubbard et al., 2020

Consequently, we interpreted the findings as both lessons learned and implications for future research. For example, the prestudy survey showed 50-86\% of participants said they needed help with critical thinking, lesson planning, learning communities, understanding "how to," assessment, and time management. In hindsight, it was evident that we concentrated on "how to" integrate the three disciplines and their standards more than other categories mentioned above. The "how to" naturally coexists with lesson planning and locating resources-those areas are inherently dependent on one another. Therefore, participants' requests, particularly, for critical thinking (86\%) and assessment (71\%) needed more attention. We did work on formative assessments for each lesson, though, perhaps assessments, the participants had in mind, were of a different type. In future research, we will ask participants to define, describe, and explain their needs more specifically before engaging them in curricular planning meetings.

We identified, at least, three crucial steps, in our project, which should have received more responsiveness from us. Participating teachers needed time and opportunities to explicitly voice their expectations before beginning the project. Highlands's school principal provided a verbal assessment regarding teachers' needs for PD; however, real teacher buy-in and shared vision, important to teachers, is crucial for successful PD (see Furco \& Moely, 2012; Tucker, 2018; Willis \& Templeton, 2017). Second, teachers needed time to actually practice lessons and strategies, they were designing for their students, before moving the lessons into classrooms. Third, there was a lack of long-term, sustainable feedback regarding teaching progress. Looking back, those actions were critical for nurturing teachers' acceptance of curriculum changes and lesson implementation with their students. Finally, this project was not focused on student achievement. There were no before and after comparative achievement tests for students; thus, teacher accountability for improved student achievement scores was not a factor.

When thinking about teachers' reactions after teaching their lessons, issues of equity emerge. Teachers, who embraced the curriculum and experiences, may continue to provide students with equitable opportunities. For example, one participant, Mr. Jones, asked for more planning time and cash subsidy (from the grant) for third-grade lesson materials. Among other resources, he bought each student a computer flash drive, and he scheduled extensive time in the computer lab, so students could freely progress on their lesson projects. Mr. Jones invited us several times to observe how his students were academically and emotionally thriving while engaged in his curricular unit. In addition, he contacted us for more PD and brought another novice teacher with him. Mr. Jones openly stated he was more interested in his students' progress as leaders and academic beings, rather than as test takers. He wanted these third graders to be challenged and excited about their learning. From our observations and interactions with all his students, we saw evolving autonomous thinkers and children who were proud of their work.

\section{Limitations}

It is important to note that between December and February, a difficult situation, beyond anyone's control, required an interim principal in the school, and by May, a full-time principal was hired. Consequently, during this year-long study, three different principals led Highlands School's faculty. The first principal instigated the project and continued as an advocate, the second principal supported the project though was not at the school long enough to engage in it fully, and the third principal (full-time) did not display interest. Findings from this study are not generalizable; participation, particularly after the first round of collaborative planning sessions, was low. We can only assume that teachers, who began the study with the first of three principals, did not feel compelled to complete the study. "New leadership at the school, district, or state level often comes with new agendas and priorities, including for PD, and education leadership turns over relatively rapidly" (Tooley \& Connelly, 2016, p. 13). The study, though, does offer a rare research example regarding K-5 ELA CCSS, science, and social studies interdisciplinary 
Hubbard et al., 2020

integration and one view of a PD model, in action, which aimed to include several elements of best practice supported by research.

\section{Conclusion}

We have argued that more experiments with PD models in diverse locations and within different cultural contexts are essential to understand the ever-changing needs and learning expectations for teachers on the job. Thus, one experience situated in a small southeastern U.S. Title 1 school is reported here. "Many PD programs are not evaluated, nor are their results communicated to other communities" (DiazMaggioli, 2004, para. 12). A learning group should responsibly generate knowledge that enriches the immediate community and also comprehensively extend to the entire teaching profession. The teaching community is not well-served when PD results are left unreported (Diaz-Maggioli, 2004), no matter the outcomes. Assessment of PD outcomes, though, is scarce due to uncertainty about the types of measurement needed and how to implement outcome measurements. "The result is that, in many locales, almost no data-either on what PD transpired or its effects-are systematically collected at all” (Tooley \& Connolly, 2016, p. 13).

Reading literature on PD best practices and implementing them, to fidelity with real teachers, are two different things. Teachers are, indeed, recipients of changing U.S. school reforms making it difficult to know the most efficient use of time and resources for various PD needs. In this particular case, prioritizing, slowing down, and deeply processing less information over longer periods of time, would have been effective methods. We observed nuanced characteristics, in this particular culture, that inform the next experience. One-on-one conversations and friendship-making-just being more casual-were needed to foster teachers' trust and support. Perhaps, those elements may not look or feel the same in different locations.

Conditions for creating higher level expectations and environments, focused on everyone learning, are particularly interesting for future research. For now, we reflect on the Highlands Elementary PD findings and how to use experiential knowledge, learned from this study, to enhance future approaches. As DiazMaggioli (2004) suggested, we wish to responsibly generate knowledge that enriches the immediate community and also comprehensively extends to the entire teaching profession. A one-size-fits-all does not work with teachers, like it does not work with students, so we call for more contextually unique studies, with teachers, to help us perfect techniques. We have seen that understanding deeply ingrained teaching traditions and norms, within the cultural setting, is the first step for successful PD.

\section{References}

Allen, R. (2006). The essentials of science, grades K-6: Effective curriculum, instruction, and assessment. Association for Supervision and Curriculum Development. http://www.ascd.org/publications/books/106206/chapters/Trends-in-Elementary-ScienceEducation.aspx

Bailey, G., Shaw, E. L., \& Hollifield, D. (2006, Fall). The devaluation of social studies in the early grades. Journal of Social Studies Research, 30(2), 18-29.

Beane, J. A. (1995, April). Curriculum integration and the disciplines of knowledge. Phi Delta Kappan International, 76(8), 616.

Bogan, B. L., King-McKenzie, E., \& Bantwini, B. D. (2012). Integrating reading, science, and social studies: Using the Bogan differentiated instruction model. U.S.-China Education Review, 12, $1053-1016$. 
Burns, M. (2014, November 26). Five models of teacher-centered professional development. Global Partnership for Education. https://www.globalpartnership.org/blog/five-models-teachercentered-professional-development/

Cervetti, G. N., Bravo, M. A., \& Barber, J. (2006). Reading and writing in the service of inquiry-based science. In R. Douglas, M.P. Klentschy, K. Worth, \& W. Binder (Eds.), Linking science and literacy in the K-8 classroom (pp. 221-224). National Science Teachers Association.

Christensen, L. M., Wilson, E. K., Anders, S. K., Dennis, M. B., Kirkland, L., Beacham, M., \& Warren, E. P. (2001, September/October). Teachers' reflections on their practice of social studies. The Social Studies, 92, 205-208.

Common Core State Standards Initiative (CCSS). (2019b). Key shifts in English language arts. http://www.corestandards.org/other-resources/key-shifts-in-english-language-arts/

Darling-Hammond, L., Hyler, M. E., \& Gardner, M. (2017). Effective teacher professional development. Learning Policy Institute.

Denton, D. W., \& Sink, C. (2015). Preserving social studies as core curricula in an era of common core reform. Journal of Social Studies Education Research, 6(2), 1-17. http://libdata.lib.ua.edu/login?url=http://search.ebscohost.com/login.aspx?direct=true\&db=eri $\underline{\mathrm{c} \& \mathrm{AN}=\mathrm{EJ} 1105364 \& \text { site }=\text { eds-live\&scope }=\text { site }}$

Diaz-Maggioli, G. (2004). Teacher-centered professional development. Association for Supervision and Curriculum Development.

http://www.ascd.org/publications/books/104021/chapters/Professional-DevelopmentToday.aspx

DuFour, R. (2004, May). What is a "professional learning community"? Educational Leadership, 61(8), 6-12.

Furco, A., \& Moely, B. E. (2012). Using learning communities to build faculty support for pedagogical innovation: A multi-campus study. Journal of Higher Education, 83(1), 128-153. https://doiorg.libdata.lib.ua.edu/10.1080/00221546.2012.11777237

Gregory, J. M. (2015, February 5). English/social studies/science: Developing an argument. School Library Monthly, 31(4), 55-57.

Haas, M. E., \& Laughlin, M. A. (2001). A profile of elementary social studies teachers and their classrooms. Social Education, 65(2), 122.

Hubbard, J. (2013) Social studies marginalization: Examining the effects on K-6 pre-service teachers and students. Journal of Social Studies Research, 37(3), 137-150.

Jensenius, A. R. (2012, March 12). Disciplinarities: intra, cross, multi, inter, trans. http://www.arj.no/2012/03/12/disciplinarities-2/

Joyce, B., \& Calhoun, E. (2015, December). Beyond professional development. Journal of Staff Development, 36(6), 42-46.

Kandel, K., \& Brew, N. (2015, February). Our science story: When science inquiry meets the common core. Science Scope, 38, 6-8.

Morris, R. C., \& Hamm, R. (1976). Toward a curriculum theory. Educational Leadership, 33(4), 299300.

National Council for the Social Studies. (1994). Expectations of excellence: Curriculum Standards for Social Studies. 
Neurendorf, K. A. (2002). The content analysis guidebook. Sage.

Novak, A. M., Hubbard, P., Ebeling, B., \& Maher, B. (2016, April/May). Explanations across the curricula: Integrating Common Core State Standards in literacy with the Next Generation Science Standards. Science Scope, 39(8), 54-60.

Nowell, S. D. (2017). "It's about the why": Social studies teachers' perceptions and pedagogy of common core literacy integration. Journal of Social Studies Research, 41(1), 63-73. https://doi.org/10.1016/j.jssr.2016.03.002

Phillips, V., \& Hughes, R. L. (2012, December 4). Teacher collaboration: The essential common-core ingredient. Education Week. https://www.edweek.org/ew/articles/2012/12/05/13hughes.h32.html

Pinar, W. F. (2012) What is curriculum theory? Lawrence Erlbaum.

Pryor, B. W., Pryor, C. R., \& Kang, R. (2016). Teachers' thoughts on integrating STEM into social studies instruction: Beliefs, attitudes, and behavioral decisions. The Journal of Social Studies Research, 4O, 123-136. https://doi.org/10.1016/j.jssr.2015.06.005

Public School Review. (2019). Profiles of U.S. public schools. http://www.publicschoolreview.com/

Ross, S. (2016). Elementary social studies instruction: Documenting teachers' perceived use of integrative practices (Doctoral dissertation). http://search.proquest.com.libdata.lib.ua.edu/pqdtlocal1006262/docview/1830471903/AC8342 $5 \mathrm{BAF} 984 \mathrm{E} 06 \mathrm{PQ} / 1$ ? accountid $=14472$

Snyder, T., \& Musu-Gillette, L. (2015, April 16). Free or reduced price lunch: A proxy for poverty? https://nces.ed.gov/blogs/nces/post/free-or-reduced-price-lunch-a-proxy-for-poverty

Strauss, A., \& Corbin, J. (1990). Basics of qualitative research: Grounded theory procedures and techniques. Sage.

Strauss, A. L., \& Corbin, J. M. (1998). Basics of qualitative research: Grounded theory procedures and techniques (2nd ed.). Sage Publications.

Stepanek, J., Appel, G., Leong, M., Turner Mangan, M., \& Mitchell, M. (2007). Leading lesson study: A practical guide for teachers and facilitators. Corwin Press.

Thomas, G. (2011). How to do your case study. Sage.

Tooley, M., \& Connelly, K. (2016, June). No panacea: Diagnosing what ails teacher professional development before reaching for remedies. New America: Education Policy. https://www.newamerica.org/documents/1518/NA NoPanaceaPaper6.1.pdf

Tucker, C. (2018, March 1). When teachers need a recharge: School leaders must offer vision and support to energize and engage teachers. Educational Leadership, 75(6), 89-91.

U.S. Department of Education, Office of Elementary and Secondary Education, Office of State Support. (2015). Improving basic programs operated by local educational agencies (Title I, Part A). https://nces.ed.gov/fastfacts/display.asp?id=158

West, A., Sullivan, K., \& Kirchner, J. (2016, April/May). How about teaching literacy with science? Science and Children, 53(8), 47-53.

Willis, J. C., \& Templeton, N. R. (2017) (2017). Investigating the establishment and sustainability of professional learning communities in rural East Texas: The principals' perspectives. Rural Educator, 38(1), 30-37. 
Hubbard et al., 2020

Young, M. (2015). Curriculum theory and the question of knowledge: a response to the six papers, Journal of Curriculum Studies, 47(6), 820-837.

https://doi.org/10.1080/00220272.2015.1101493

\section{[Appendices follow]}




\section{Appendix A}

\section{Prestudy In-Service Teacher Survey}

Please review the list of topics and check "yes" or "no" on areas in which you believe that you need jobembedded professional development.

\begin{tabular}{|c|c|c|}
\hline Topic & Yes & No \\
\hline $\begin{array}{l}\text { Understanding why an integrated approach to using English language arts Common Core } \\
\text { standards to teach content disciplines such as social studies and science might be useful in } \\
\text { your classroom. }\end{array}$ & & \\
\hline $\begin{array}{l}\text { Understanding how English language arts Common Core standards for your grade level can } \\
\text { be used to teach social studies and science. }\end{array}$ & & \\
\hline $\begin{array}{l}\text { Developing daily lesson plans for classroom instruction that use English language arts } \\
\text { Common Core standards to teach social studies and science. }\end{array}$ & & \\
\hline $\begin{array}{l}\text { Developing long-term lesson units for classroom instruction that use English language arts } \\
\text { Common Core standards to teach social studies and science. }\end{array}$ & & \\
\hline $\begin{array}{l}\text { Learning how to use engaging strategies to integrate English language arts Common Core } \\
\text { standards with social studies and science. }\end{array}$ & & \\
\hline $\begin{array}{l}\text { Learning how to use technological techniques to integrate English language arts Common } \\
\text { Core standards with social studies and science. }\end{array}$ & & \\
\hline $\begin{array}{l}\text { Accommodating individual student needs while using English language arts Common Core } \\
\text { standards to teach social studies and science. }\end{array}$ & & \\
\hline $\begin{array}{l}\text { Time management strategies while using English language arts Common Core standards to } \\
\text { teach social studies and science. }\end{array}$ & & \\
\hline $\begin{array}{l}\text { Incorporating critical thinking while using English language arts Common Core standards to } \\
\text { teach social studies and science. }\end{array}$ & & \\
\hline $\begin{array}{l}\text { Using formative and summative assessments to assess student learning while using English } \\
\text { language arts Common Core standards to teach social studies and science. }\end{array}$ & & \\
\hline $\begin{array}{l}\text { Establishing effective communication with parents, students, and other teachers about using } \\
\text { Common Core Standards in an integrative approach to teaching various content } \\
\text { disciplines. }\end{array}$ & & \\
\hline $\begin{array}{l}\text { Creating learning communities that foster collaboration among co-workers when planning } \\
\text { for the use of English language arts Common Core standards while teaching social studies } \\
\text { and science. }\end{array}$ & & \\
\hline $\begin{array}{l}\text { Learning more about locating teaching resources when using English language arts Common } \\
\text { Core standards to teach social studies and science. }\end{array}$ & & \\
\hline
\end{tabular}




\section{Answer the following questions concerning implementation of English language arts Common Core standards.}

1. Please list/describe challenges you see to implementing English language arts Common Core standards.

2. Please list/describe concerns you have about lesson and unit planning when using English language arts Common Core standards to teach social studies and science.

3. Please list/describe any questions you have about the implementation of English language arts Common Core standards when teaching social studies and science.

4. What are your perceptions about participating in a demonstration lesson (modeled by others) that integrates English language arts Common Core standards with social studies and science?

5. What are your perceptions about participating in job-embedded professional development to co-plan lessons and/or units, for your class, that integrate English language arts Common Core standards with social studies and science? 


\section{Appendix B}

\section{Prestudy In-Service Teacher Focus Group Interview Questions}

What convinced you to participate in this study?

What has been your experience in planning and implementing lessons and/or units with the new state adopted English language arts Common Core standards (College and Career Ready Standards) so far?

Please describe any challenges you anticipate or concerns you have about the implementation of the new state adopted English language arts Common Core standards.

Given your experiences in teaching reading, science, and social studies, how do you see the Common Core Standards impacting those subjects and the way you teach them?

What are your perceptions of job-embedded professional development and how it could help or hinder your success at implementing English language arts Common Core standards?

What are your perceptions of an integrated approach in which English language arts Common Core standards are used to teach science and social studies? 


\section{Appendix C}

\section{Poststudy In-Service Teacher Survey}

After your participation in the job-embedded professional development, please review the list of topics and check areas that represent your current perceptions.

\begin{tabular}{|c|c|c|c|}
\hline Topic & Yes & No & $\begin{array}{l}\text { I need more } \\
\text { professional } \\
\text { development in } \\
\text { this area }\end{array}$ \\
\hline $\begin{array}{l}\text { Did you gain knowledge about why an integrated approach to using English } \\
\text { language arts Common Core standards to teach social studies and science } \\
\text { might be useful in your classroom? }\end{array}$ & & & \\
\hline $\begin{array}{l}\text { Did you gain knowledge about how English language arts Common Core } \\
\text { standards for your grade level can be used to teach social studies and } \\
\text { science? }\end{array}$ & & & \\
\hline $\begin{array}{l}\text { Did you gain knowledge about how to develop daily lesson plans that use } \\
\text { English language arts Common Core standards to teach social studies and } \\
\text { science? }\end{array}$ & & & \\
\hline $\begin{array}{l}\text { Did you gain knowledge about how to develop long-term lesson units that } \\
\text { use English language arts Common Core standards to teach social studies } \\
\text { and science? }\end{array}$ & & & \\
\hline $\begin{array}{l}\text { Did you gain knowledge about engaging strategies to integrate English } \\
\text { language arts Common Core standards with social studies and science? }\end{array}$ & & & \\
\hline $\begin{array}{l}\text { Did you gain knowledge about technological techniques to integrate English } \\
\text { language arts Common Core standards with social studies and science? }\end{array}$ & & & \\
\hline $\begin{array}{l}\text { Did you gain knowledge about how to accommodate individual student's } \\
\text { needs while using English language arts Common Core standards to teach } \\
\text { social studies and science? }\end{array}$ & & & \\
\hline $\begin{array}{l}\text { Did you gain knowledge about time management strategies while using } \\
\text { English language arts Common Core standards to teach social studies and } \\
\text { science? }\end{array}$ & & & \\
\hline $\begin{array}{l}\text { Did you gain knowledge about how to incorporate critical thinking skills } \\
\text { while using English language arts Common Core standards to teach social } \\
\text { studies and science? }\end{array}$ & & & \\
\hline
\end{tabular}




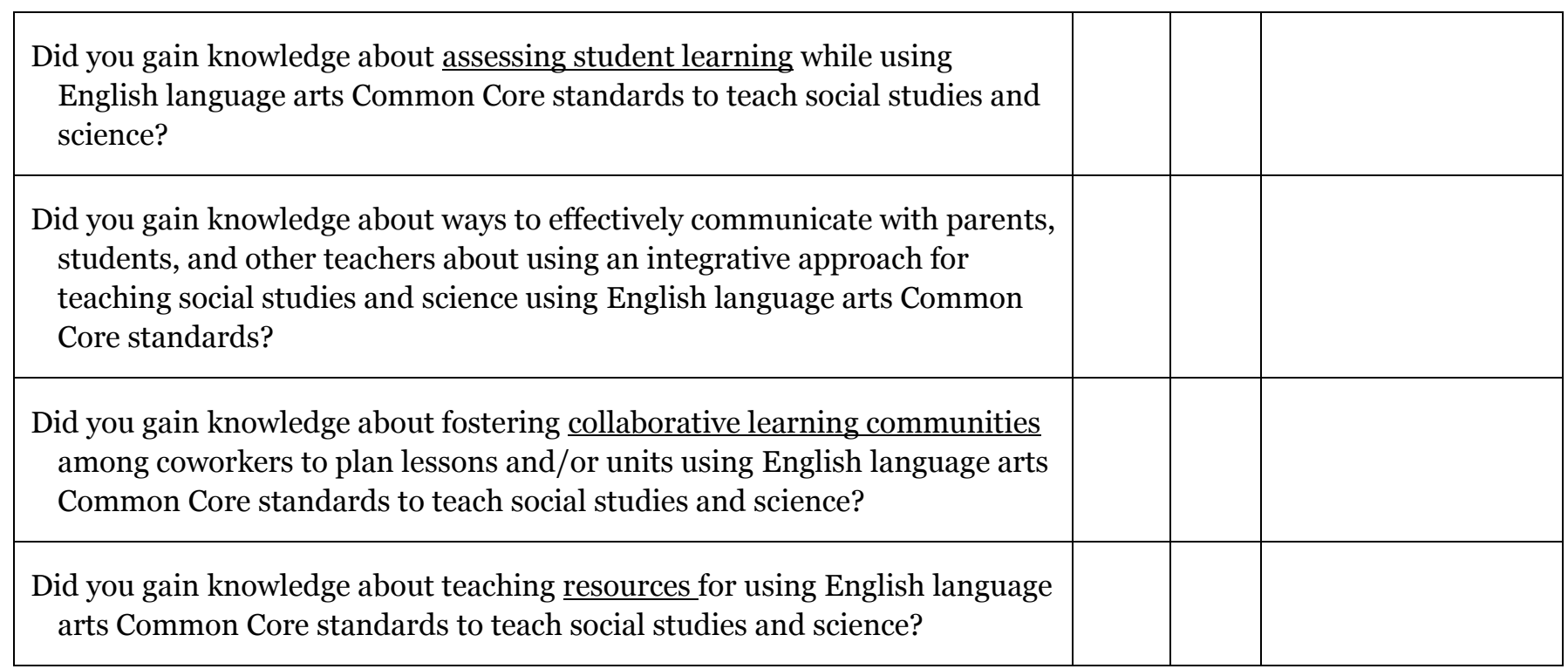

After reflecting on your participation in the job-embedded professional development, please answer the following questions concerning your experiences in planning and implementing the English language arts Common Core standards to teach social studies and science.

1. Please list/describe challenges you see to implementing English language arts Common Core standards with your class.

2. Please list/describe concerns you have about lesson and unit planning when using English language arts Common Core standards to teach social studies and science.

3. Please list/describe any questions you have about the implementation of English language arts Common Core standards when teaching social studies and science.

4. What are your perceptions about participating in a demonstration lesson (modeled by others) that integrated English language arts Common Core standards with social studies and science?

5. What are your perceptions about participating in job-embedded professional development to coplan lessons and/or units, for your class, that integrated English language arts Common Core standards with social studies and science?

6. Did your students benefit from the implementation of the integrated lesson or unit that you developed? 
Hubbard et al., 2020

\begin{tabular}{|l|l|c|c|c|}
\hline & $\begin{array}{c}\text { Very } \\
\text { much }\end{array}$ & $\begin{array}{c}\text { To } \\
\text { some } \\
\text { extent }\end{array}$ & $\begin{array}{c}\text { Not } \\
\text { much }\end{array}$ & $\begin{array}{c}\text { Not at } \\
\text { all }\end{array}$ \\
\hline Overall academic achievement & & & & \\
\hline Student interest/enjoyment & & & & \\
\hline Student motivation & & & & \\
\hline Student involvement & & & & \\
\hline Student curiosity & & & & \\
\hline Student confusion & & & & \\
\hline Student acceptance & & & & \\
\hline
\end{tabular}

Please add additional comments. 


\section{Appendix D}

\section{Poststudy In-Service Teacher Focus Group Interview Questions}

What in particular worked for you when implementing English language arts Common Core standards to teach social studies and science through the integrated approach?

What were challenges or barriers you faced when teaching English language arts Common Core standards with discipline-integrated lessons and/or units? How did you overcome those barriers?

In what ways, if any, has your planning and teaching changed as a result of this particular job-embedded professional development and discipline-integrated planning and teaching?

Do you plan to continue teaching the English language arts Common Core standards with integrated lessons and/or units? If so, what changes will you make? If not, please provide an explanation for why the methodology did not work for you?

How has teaching English language arts Common Core standards using the integrated approach impacted the atmosphere in your classroom?

What changes, if any, have you seen in your students as a result of implementing the integrated approach to teaching English language arts Common Core standards with social studies and science in your classroom?

What are your perceptions of job-embedded professional development to co-plan and implement integrated lessons and units? 


\section{Appendix E}

\section{Example Quotes From the Open-Ended Survey Questions}

1. Please list/describe challenges you see to implementing English language arts Common Core standards with your class.

Participant 1: "planning time"

Participant 2: "locating sufficient resources"

Participant 3: "finding engaging literature, although that was expected and will improve as I teach Common Core for years"

Participant 4: "The only challenge I found was materials and time"

2. Please list/describe concerns you have about lesson and unit planning when using English Language Arts Common Core Standards to teach social studies and science.

Participant 1: "planning time"

Participant 2: "When teaching ELA Common Core, I have found it better to teach a skill and focus on it. Integration of science and social studies uses lots of reading skills, best left as a review"

3. What are your perceptions about participating in job-embedded professional development to coplan lessons and/or units, for your class, that integrated English language arts Common Core standards with social studies and science?

Participant 1: "Unsure"

Participant 2: "professional development would be helpful as common core is put into more and more practice"

Participant 3: "very interested"

Participant 4: "I believe that participating in job-embedded PD is the most effective kind!"

4. Did your students benefit from the implementation of the integrated lesson or unit that you developed?

\begin{tabular}{|l|c|c|c|c|}
\hline & $\begin{array}{c}\text { Very } \\
\text { much }\end{array}$ & $\begin{array}{c}\text { To } \\
\text { some } \\
\text { extent }\end{array}$ & $\begin{array}{c}\text { Not } \\
\text { much }\end{array}$ & $\begin{array}{c}\text { Not at } \\
\text { all }\end{array}$ \\
\hline Overall academic achievement & 4 & & & \\
\hline Student interest/enjoyment & 4 & & & \\
\hline Student motivation & 4 & & & \\
\hline Student involvement & 4 & & & \\
\hline Student curiosity & 4 & & & \\
\hline Student confusion & 2 & & & 2 \\
\hline Student acceptance & 4 & & & \\
\hline
\end{tabular}

5. Please add additional comments.

Participant 1: "You did a great job"

Participant 2: "It was used as a review of several skills as opposed to teaching a new one"

Participant 3: "Yes - everything except student confusion"

Participant 4: "Can we have more please? HaHa [happy face symbol inserted]" 
Hubbard et al., 2020

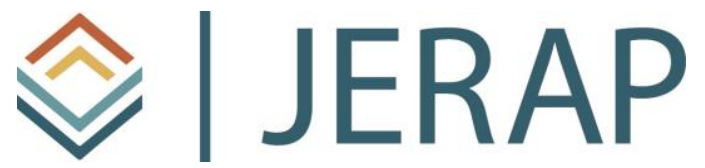

The Journal of Educational Research and Practice is a peerreviewed journal that provides a forum for studies and dialogue about developments and change in the field of education and learning. The journal includes research and related content that examine current relevant educational issues and processes. The aim is to provide readers with knowledge and with strategies to use that knowledge in educational or learning environments. JERAP focuses on education at all levels and in any setting, and includes peer-reviewed research reports, commentaries, book reviews, interviews of prominent individuals, and reports about educational practice. The journal is sponsored by the Richard W. Riley College of Education and Leadership at Walden University, and publication in JERAP is always free to authors and readers. 